\title{
Curriculum Change and Development in Malawi: A Historical Overview
}

\author{
Grames Chirwa \\ Department of Education and Curriculum Studies, University of Johannesburg, \\ 09 Aukland Park Avenue,Aukland Park Corner University Road and Kings Way,Johannesburg, 2006. \\ Email: grameschirwa@yahoo.co.uk \\ Devika Naidoo (PhD) \\ Department of Education and Curriculum Studies, University of Johannesburg, Office 406,Aukland Park \\ Email: devikan@uj.ac.za

\section{Grames Chirwa} \\ Department of Education and Curriculum Studies, University of Johannesburg,09 Aukland Park Avenue, \\ Aukland Park Corner University Road and Kings Way, \\ Email: Johannesburg, 2006
}

\section{Doi:10.5901/mjss.2014.v5n16p336}

\begin{abstract}
To improve the quality of primary education in Malawi, the national government embarked on curriculum reform in 2001 and adopted an Outcomes Based curriculum in 2007. The new curriculum differs radically from its predecessors. This paper employs a historical approach to explore pre-colonial, colonial and post-colonial curriculum change and development in Malawi. The origin and attributes of the present OBE curriculum is emphasized and an attempt is made to explain the forces and imperatives that shaped it. This conceptual paper focuses on the process and rationale that resulted in the decision to revive the primary curriculum in 2001 to come up with an outcomes-based curriculum, and the influence of the first post-apartheid South African curriculum $(\mathrm{C} 2005,1998)$ on the design features of the new curriculum in Malawi. It is based on primary sources such as curriculum documents and secondary sources on curriculum development in Malawi. The paper raises concerns relating to 'unproblematic burrowing' of curriculum policies from South Africa, given the review and revision of C2005 in South Africa in 2000.
\end{abstract}

Keywords: Curriculum, Primary Curriculum and Assessment Reform, 'unproblematic burrowing.'

\section{Introduction}

The values and norms of a society are embedded within its national curriculum. The curriculum is a tool through which the values, needs, aspirations, interests and objectives of the society or the nation are articulated and addressed as learning experiences for the development of the individuals through teaching and learning process (Apple, 1979). Tanner and Tanner, (1995) looked at curriculum as, "the planned and guided learning experiences and intended outcomes formulated through systematic reconstruction of knowledge and experiences under the auspices of the school, for learners' continuous and wilful growth in personal social competence" (p.158). As such, it should be relevant, appropriate and responsive to the needs of individual learners and the society at large. In addition to being influenced by internal historical, economic, social and political factors, the national curriculum is also influenced by external conditions and ideas. Chisholm (2005) argues that the wind of curriculum change sweeping across nations, especially in Southern Africa is due to the phenomenon of globalisation, rather than just the desire of individual nation states.

Chisholm (2005) holds that the concept of globalization and its relationship to national education systems has enjoyed considerable prominence ( $p$ 79). According to Chisholm, globalization and international influences have led to increasing convergences of ideas and practices (including those of education) across national contexts ( $p 7$ ). Thus the agenda for education is increasingly being set globally (Dale and Robertson, 2002).

According to Chisholm, the links between global, regional, national and local educational contexts need not necessarily be understood in either a downward or upward simple linear manner. She argues that policies can circulate between levels, moving down from the international to the national and back to the regional, being reshaped in each 
stage and process to suit local circumstances (p81). Chisholm argues that the South African government's powerful role within the region is 'likely to privilege adoption of its policies rather than the other way around' (p82), exposing the nation states within the region to the danger of unproblematic borrowing which could be hazardous as curricula get implemented in contexts different from where it was conceived.

However, while the concept of globalization might explain the convergence of education and curriculum ideas across national contexts in the intended curriculum, it cannot explain differences in implementation (Steiner-Khamsi, 2000) in different national contexts, history and educational debates within nation states (Chisholm, 2005).

\section{Methodology}

This paper is located within a larger study of the history of curriculum reforms in Malawi, starting from pre-colonial period to date. It is based on an analysis of primary sources such the Primary and Assessment Framework, a Malawi government policy document which guided the development of the new Outcomes-Based curriculum in Malawi and the Malawi Institute of Education curriculum document on curriculum reviews which have been taking place in the Southern African Development Community countries, entitled, 'Curriculum and Assessment in the 21 ${ }^{\text {st }}$ Century,' and secondary sources such as academic papers and published papers on curriculum developments in Malawi and Africa in general, such as 'Some key issues in African Traditional Education' by Adeyemi and Adeyinka (2002) and 'Curriculum Development in Nigeria; Historical Perspectives' by Oluniyi and Olajumoke (2013).

\section{Pre-Colonial Period: Traditional/Indigenous Curriculum}

Before the introduction of formal education in Malawi by the missionaries, education in the country, like in many other African countries was purely traditional or indigenous (Adeyemi and Adeyinka, 2002). It involved intellectual, physical and attitudinal training to develop younger generation into acceptable adults in the society. Firstly, it had its foundation in the five principles of preparationism, functionalism, communalism, perennialism and holisticism. The principle of preparationism, implied that the role of learning and teaching was to equip boys and girls with the skills appropriate to their gender in preparation for their distinctive roles in the society. The education was gendered, with boys and girls receiving that kind of education which enabled them to fulfil socially defined masculine and feminine responsibilities respectively. Male education thus produced farmers, warriors, blacksmiths, rulers and other male dominated occupations from which women were excluded. On the other hand, female education was predominantly designed to produce future wives, mothers and home-makers. The principle of preparationism further meant that male and female education prepared its recipients to adjust to the community and to play a useful role in it. Children developed a sense of obligation towards the community and grew to appreciate its history, language, customs and values. According to Adeyemi and Adeyinka (2001), this is perhaps one of the greatest attributes of indigenous education as opposed to Western education which tended to alienate young Africans from their cultural heritage.

Related to the principle of preparationism was the principle of functionalism.

The traditional educational practices in Malawi, just like in other precolonial African societies were predominantly utilitarian (Adeyemi and Adeyinka, 2002). It was a participatory kind of education in which learning happened through imitation, initiation ceremonies, work, play, and oral literature. In this way, the learner was productive as he/she learned and was smoothly integrated into the community and according to Adeyemi and Adeyinka, 2002, the gap which today exists between study and the world of work was absent in pre-colonial society, and there was no unemployment in African traditional societies.

The third principle of traditional education was communalism. In African traditional education, all members of the society owned things in common and applied the communal spirit to life and work. Children belonged to the community and every member of the community had a part or a stake in their upbringing. For example, if a child misbehaved while the parents were not present, any other adult member of the community could discipline and correct him/her on the spot.

Perennialism constituted the fourth philosophical foundation of indigenous education. Most traditional communities in Africa perceived education as a vehicle for maintaining or preserving the cultural heritage and status quo. Traditional teachers thus discouraged pupils from experimenting with the unknown and imposed heavy sanctions on those who tried to do so. Thus education in indigenous African communities was conservative.

The fifth principle of traditional or customary education in Malawi was holisticism or multiple learning. Education provided little or no room for specialisation, but equipped both boys and girls to undertake a multitude of occupations that required related skills. For example, a child destined to become a fisherman, as already learned not only to catch fish but also to preserve and market it; to make and mend nets; to manufacture canoes and to erect temporary fishing huts. The 
holistic nature of customary education enabled young people to acquire a variety of skills that made them productive in many ways.

Secondly, the content of traditional education was based on the physical, social and spiritual environments of the time. The physical environment influenced the content of the curriculum in that what was taught was meant to assist the child to adjust and adapt to the environment in order to exploit and derive benefit from it. As Adeyemi and Adeyinka (2002) argues, "Whether the child's habitat was dominated by mountain, plain, river or tropical forest, he had to learn to combat its dangers and to use its fertility"(p.233). To come to terms with the physical environment, the growing child learned about landscape, the weather and also about both plant and animal life. As the child grew, he/she learned to understand the uses of both plants and animals in his locality, in addition to the taboos associated with them. The physical situation further influenced what practical skills the child learned in order to prepare him or her for future responsibilities. Boys and girls who lived in fishing areas, for example, learned such skills as were required to catch, preserve and market fish, and manufacture and mend fish traps, nets and canoes.

The content of the traditional curriculum in Malawi was also derived from the spiritual environment. In pre-colonial Africa, where every event (like the birth of a child, death, sickness, flood or drought) was accorded spiritual significance, education tended to focus on religious teaching or instruction. According to Adeyemi and Adeyinka (2002) young children received instruction on the influence of both malevolent and benevolent spirits, and purification practices they were also taught the value of propitiating the spirits to avert such disasters as sickness, death and pestilence.

Thirdly, there was no explicitly defined method of instruction and no standardised method of assessing the learners for purposes of graduation and certification as is the case in present-day educational institutions. Learning was mainly by initiation, observation and repetition of what parents and other adults did. Another mode was through oral literature and play. Parents were predominantly responsible for teaching their children.

Traditional education was utilitarian, localising, parochial and communal. It focused almost exclusively on the clan or tribe and hardly prepared its recipients for outside contact. Practically, this meant that the skills and knowledge possessed by a given ethnic group could not be easily transmitted to another tribe (Adeyemi and Adeyinka, 2002). In spite of its shortcomings however, traditional education was an effective way of preparing young people for life in their communities. In corroboration, Oluniyi (2013) holds that the informal curriculum in Nigeria 'was not an end in itself or for mere certification without assurance of being employed' and that there was training going on that inspired competence, developed skills and enabled the acquisition of knowledge (Oluniyi, 2013, p.73).

When the Christian missions came to Malawi in the fifteenth century, they introduced formal education with its emphasis on literacy. African parents readily accepted this new education and they began to send their children to the schools, gradually setting aside their traditional education. The Christian mission's education and its curricula are discussed next.

\section{The Missionary Period}

Malawi's present formal education system was born out of the works of early missionaries, notably, Robert Laws of the Free Church of Scotland, who in 1875 opened the first school at Cape Maclear in Southern Malawi (Galimoto, 2008). The main purpose of the missionary schools, was - in the missionaries' eyes - to 'civilise the primitive and pagan natives' by teaching them Christian values.

Several missions were established in different parts of the country, each establishing an education system based on its own religious philosophies blended with the characteristics of the communities they were working in. For example, attempts to introduce education into Malawi were made by the Catholic, the Dutch Reformed Church and the Seventh Day Adventists who followed the United Free Church of Scotland and established mission stations in various parts of the country. As the Phelps-Stoke Commission (1924) comments: 'Education was at all times of secondary importance to evangelization. Education made people literate and this meant that they could read the Bible.'

A common feature of the curriculum of the missionary education was reading, writing and arithmetic, with some missions placing emphasis on technical skills. However, the missionaries merely wanted to evangelise Malawi. This was the case not only in Malawi but also in other African countries as well. Countries like Zambia (Robertson, 1970), Lesotho (Mohapeloa, 1982) and Kenya (Indire, 1983) all report the central position of the missionaries in introducing education in these countries as a pre-requisite to evangelization. In Malawi, by the year 1900, various educational reports indicated that missionary activities had spread to most parts of the country; reading, writing, arithmetic and bible study formed the major part of educational activities. The government, in recognition of the missionary work in education, introduced a grant-aided system. The funds provided by the government were shared by the missionaries in proportion to their educational activities. It was not until 1926, according to the Nyasaland Annual Education Report (1961), that the 
government established a Department of Education to co-ordinate all missionary educational activities in the country. Due to financial constraints, the missions were moving toward some kind of partnership with the government in education by 1925. The Jones (2005) missionary comment stated:

It seems to us quite evident that in view of the present financial stringency, neither the Government nor the missionary facilities can carry on the work alone, but that working in conjunction, we can bring to a successful issue the aims which we both have at heart (Jones, 2005, p. 1)

The Phelps-Stokes Commission, a privately instituted but missionary inspired commission, recommended that the missionaries and the colonial government should combine their efforts to provide education to Malawians. This recommendation was adopted by the colonial government in its Colonial Office Memorandum of 1925 entitled, "Education Policy in British Tropical Africa." The government accepted to enter into partnership with the missions in the provision of education to Malawians. The Department of Education was therefore established in 1926 to co-ordinate all educational activities in the country. This included the provision of a central curriculum for all schools by 1933, except for religious education, which was left to the individual missionaries to handle. The type of curriculum during the colonial period is discussed below.

\section{The Curriculum of the Colonial Period}

Malawi was under British colonial rule from 1891 to 1964. The colonial government started to feature in education in 1926 when the Department of Education was established.

The Government's aim in education was to provide a small but efficient system to fulfill clearly identified goals of the country, such as national development, while the missionaries held on to their original goal to "Christianise" the country. The goals of colonial education were: personal hygiene, use of the environment, home life, use of leisure time, literacy and numeracy, moral development and religious life (Galimoto, 2008). The missions however still controlled the delivery of education because the government released only small grants to the missions. Differences also existed among the missionaries themselves in the way schools were run and organized. For example, some missions wanted education to go beyond fulfilling the objective of evangelization and provide vocational training. The 1960 report (Galimoto, 2008) commented that some missions adopted procedures that allowed pupils, who showed interest and were academically promising, to be trained to start demonstration schools of their own, while the less promising were taught practical subjects. In some missions, capable students were sent for missionary training so that on their return they could open substations. By 1900, mission stations were established in most parts of the country and education became one of the major activities of missionary work.

The use of the central curriculum, mentioned above, became the only unifying factor among the various missionaries in providing education, and the idea of central curriculum has remained in use up to the present day, although missions no longer control education.

The curriculum of primary education during the colonial period changed in 1940 when the first secondary school was opened by protestant missions in Blantyre. The secondary school curriculum was based on the academic-elitist systems of the English Grammar School. History, Geography, English literature, English language, Latin, General Science, Mathematics, Religious knowledge and Chichewa were the core subjects. As a result, the primary curriculum had to change to meet these requirements and as can be imagined with disastrous results. The content and learning materials were based on British experiences and had little bearing on the local situation. Europeans teachers taught so as to enable pupils to pass examinations. Soon after independence in 1964, the government instituted a commission to review the education system in the country. The commission, known as Johnson-Survey Team observed that the education system in Malawi was 'imported, excessively academic, deadly passive and addicted to rote learning' (Kabwila, 1995). A need therefore arose to overhaul the colonial education system. The independent government attempted to do this by drawing educational plans and reviewing the colonial government's curriculum. I now turn to a review of primary education after independence in 1964.

\section{Post-Colonial, One Party-Rule Period}

When Malawi became independent in 1964, it became imperative that the curriculum be reformed so that it would be relevant to the needs and challenges of an independent nation (Kabwila, 1995, Lowe, 2008). It became clear that the curricula inherited from the colonial government did not address the need and the challenges of the independent Malawi. The country needed agriculturalists, carpenters, engineers, social specialists, community workers, teachers, nurses and construction workers. There was a significant discrepancy between the goals of the current curricula and the needs of the 
country. The country therefore launched its first Educational Plan in 1973 which was to provide guidelines for the development of the education curriculum of the independent Malawi. The plan had the following major objectives;

a. the fulfilment of the specific needs of the labour market.

b. the development of a school curriculum with relevance to the socio-economic and environmental needs of the country.

c. the improvement of efficiency in the utilization of existing facilities; and

d. the achievement of a more equitable distribution of educational facilities and resources.

( Kabwila, 1995)

Following the launching of its first Educational Plan in 1973, a primary curriculum review was then carried out in 1982, with the overall aim of improving the quality of education. In the 1982 curriculum, Agriculture became a common subject of instruction in both primary and secondary school. This was mainly due to the fact that the country needed its populace to have agricultural knowledge as its economy is agriculture-based. The number of subjects on offer in both the primary and secondary school also increased compared to those in the colonial government's curricula. The new curriculum had 14 subjects; Agriculture, Chichewa, English,

Creative Arts, Social Studies, Mathematics, Music, Physical Education, Religious Studies, Bible-Knowledge, Needlecraft, Home Economics, Science/Health Education and Life skills. The emphasis on external examination as in the colonial period adopted by the newly independent Malawi government militated against change.

According to Lowe $(2008$, p. 3), the curriculum had changed very little since external examinations still controlled the whole system of education...so long as external

examinations were part of the Malawi educational system, no real progress would be made towards realisation of the aims of education initiated after independence.

The first Education Plan put into place by post-independent Malawi government seem to have been wrought with problems although there is need to celebrate the fact that the Plan was a valuable document as it marked the real first attempt at educational planning since the advent of education in Malawi by the missionaries. There was general dissatisfaction with the 1982 curriculum as it was too academic and exam-oriented (Kabwila, 1995; Khomani, 2005). The 1982 curriculum had to be reviewed from 1987. In the words of Khomani (2003, p.5), there are a number of factors which necessitated the review from 1987. One of the factors is that the 1982 curriculum was overloaded with subjects of study. There were excessive overlaps in the nature of content across subjects without any deliberate effort to integrate such content. By its design and balance, the curriculum was examination-oriented with the greatest stress on cognitive skills rather than on social or practical skills.

The introduction of the national curriculum and assessment reform in 2007 (the one which this paper is concerned about) by the Ministry of Education can be seen as the government's realization that change of external examination policy is an important determinant of real change in education system and an important prerequisite for realisation of the aims of education initiated after independence. This led to the Malawi government's Second Education Plan which covered the period 1985-1995. The overall objective of this plan was to improve the quality of education so that it met the needs of the country. According to this Education Plan, the quality of education was to be improved through reviewing the 1982 curriculum. Justifying the need for reviewing the 1982 curriculum, the Secretary of Education (1991) in the foreword of the Primary School Syllabus said, 'Nothing is more difficult in the field of education than to plan appropriate curricula to achieve the goals set for the individual and national development.' He continued to specify the pertinent areas that needed urgent attention. He said,

\footnotetext{
Bearing in mind that primary education is terminal for the majority of the children, there should be greater emphasis on those practical skills that would enable them to enter self employment and entrepreneurship and those skills that relate to the social-economic development of the country (p. 1, cited in Kabwila, 1995).
}

The responsibility to plan, develop and produce the revised curriculum was given to the Malawi Institute of Education which was mandated to:

a. design, develop, monitor and evaluate the national education curriculum to ensure that it continues to respond to

b. the present and future needs of the Malawi society.

c. assist in the training of teachers

d. provide professional help and services for teachers

e. arrange for the publication and production of teaching/learning materials 
(MIE Library News, 2008, p.1)

The Malawi Institute of Education produced curriculum materials for the primary schools and primary teacher education for the revised curriculum in 1982. Following the introduction of the Second Education Plan, the Institute followed with plans to produce new curriculum materials as well as organise in-service education for teachers. The 1982 curriculum had to be reviewed in 1991.

Paradoxically, when the 1991 curriculum was developed, it appears to have had almost the same problems as the 1982 curriculum, problems like a large number subjects and it is argued to have been examination-oriented.

The 1991 curriculum had again to be reviewed in 2001 by the multi-party democratic government which established its own ways of running education, examples of which are described in the next sub-section. Table1 below summarises curriculum change and development in Malawi from pre-colonial period to multiparty democratic period and the curriculum focus of those periods.

\begin{tabular}{|c|c|c|c|}
\hline Period & Year & Curriculum Focus & Curriculum Content \\
\hline Traditional & $\begin{array}{l}\text { Up to } \\
1800\end{array}$ & $\begin{array}{c}\text { preparationism, functionalism, } \\
\text { communalism, perennialism and } \\
\text { holisticism }\end{array}$ & $\begin{array}{l}\text { Erecting huts; catching, preserve and marketing fish; making and } \\
\text { mending nets; manufacturing canoes, etc. }\end{array}$ \\
\hline Missionary & $\begin{array}{c}1800- \\
1926\end{array}$ & Literacy for reading the Bible & Reading, Writing and Arithmetic \\
\hline Colonial & $\begin{array}{l}1926- \\
1964\end{array}$ & Education for development & $\begin{array}{l}\text { Personal hygiene, use of the environment, home life, use of leisure } \\
\text { time, literacy and numeracy, moral development and religious life. }\end{array}$ \\
\hline $\begin{array}{l}\text { Post-colonial period; } \\
\text { first educational plan }\end{array}$ & $\begin{array}{l}1973- \\
1985\end{array}$ & Agriculture knowledge & $\begin{array}{l}\text { Agriculture, Domestic and Personal Hygiene, Environmental } \\
\text { studies, Nature Science, General Science, Chichewa, English, } \\
\text { Mathematics, Music, Physical Education, Religious Studies, Bible- } \\
\text { Knowledge, Home-economics and Needlecraft }\end{array}$ \\
\hline $\begin{array}{l}\text { Second educational } \\
\text { plan }\end{array}$ & $\begin{array}{l}1985 \text { to } \\
1995\end{array}$ & Literacy and Numeracy skills & $\begin{array}{l}\text { Agriculture, Chichewa, English, Creative Arts, Social Studies, } \\
\text { Mathematics, Music, Physical Education, Religious Studies, Bible- } \\
\text { Knowledge, Needlecraft, Home Economics, Science/Health } \\
\text { Education and Life skills. All subjects being externally examined }\end{array}$ \\
\hline $\begin{array}{l}\text { Primary Curriculum } \\
\text { and Assessment } \\
\text { Reform }\end{array}$ & $\begin{array}{l}2001 \text { to } \\
\text { date }\end{array}$ & $\begin{array}{l}\text { Practical skills for entering self } \\
\text { employment and } \\
\text { entrepreneurship }\end{array}$ & $\begin{array}{l}\text { Chichewa, English, Mathematics, Expressive Arts } \\
\text { Religious Education, Bible Knowledge, Life Skills, Social and } \\
\text { Environmental Sciences, Agriculture and Science and Technology }\end{array}$ \\
\hline
\end{tabular}

In 1994, when Malawi went through a political transition from a one-party dictatorship to a multi-party government came the imperative to reform the curriculum. In 2001, the Malawi Ministry of Education and Vocational Training through the Malawi Institute of Education, the country's national curriculum development centre embarked on a national primary curriculum and assessment reform, with the support of international donor agencies; namely, Department for International Development (DfID) of Britain, German Technical Co-operation (GTZ) and United States Agency for International Development (USAID) and other organizations proposed a radical curriculum review in 2001. The government, with technical and financial assistance from the aforementioned donors produced guidelines for developing the new curriculum, which was named 'Curriculum and Assessment Framework. The new curriculum was implemented in 2007.

According to the Curriculum and Assessment Framework (CASF) (MOE, 2006) there were many factors that influenced the curriculum reform. Most of the factors were educational but others were political, social and economic. From the political side, Malawi had changed from single party system of government to multi-party system of government. The change brought with it a number of issues which needed to be addressed through the education system. One of the issues was democracy and its related concept of human rights which seemed to be misunderstood by people including learners (MOE, 2006). Socially, Malawi had not been spared by global challenges such as the HIVIAIDS pandemic, environmental degradation and gender disparities. In addition, the country experiences one of the fastest growing populations in the world (UNDP, 2000). Economically, Malawi as a country is rated at 164 out of 177 on the poverty index and most people live below the poverty line (WFP, 2009). Furthermore, there are few job opportunities and the 1991 curriculum was not preparing the learners for self employment in case of failure to go beyond primary education. Many Malawians thus felt that the 1991 curriculum had not performed and therefore the need to reform the curriculum so that a new curriculum takes on board all these issues (Chilimanjira, 2011).

The education system, in particular, the primary sector faced many challenges with the 1991 curriculum. The curriculum was overloaded with a total of 14 subjects. The subjects were: Chichewa, English, Creative Arts, Social Studies, Mathematics, Music, Drama, Physical - Education, Religious Studies, Needlecraft, Agriculture, Home 
Economics, Science/Health-Education and Life skills. The subjects were overlapping which resulted in a lot of duplication and redundancy both within and across the subjects (Khomani, 2003). Since the curriculum was also examination driven, teachers concentrated on teaching content that was examinable and subjects that were examined such as Mathematics at the expense of other equally important subjects such as Life skills. In addition because of the examination orientation and curriculum overload, teachers rushed through the content to cover the syllabus (MIE, 2007; Chilora, 2007; MOE, 2006). Teachers thus focussed on teacher centred methodologies and on teaching at the expense of learning (MIE, 2007; Chilora, 2007; MOE, 2006).

\section{Design of the Malawi Outcomes-Based Curriculum}

The initiators of the new curriculum, Malawi Institute of Education, indicated that the curriculum was intended to reflect the societal needs and skills required to the learners with the ability to live a meaningful life in their communities. The key design features of the new curriculum are; Outcomes Based Education, Learner-Centred Pedagogies, Indigenous Knowledge and Continuous Assessment. The outcomes to be achieved at different stages of the learning process in the new curriculum are:

(a) Developmental outcomes: describe what the learner is expected to achieve by the end of the primary cycle.

(b) Primary outcomes: what the learners should know, should be able to do and the desirable attitudes that they should display by the end of the primary cycle for each Learning Area.

(c) Assessment standards: indicate the agreed basic level of knowledge, concepts, skills and desirable attitudes the learners must demonstrate or display during and at the end of each standard from Standard 1 to Standard 8. They are bench marks for learner achievement in each standard or school year (Ministry of Education, 2006).

Secondly, the curriculum advocates for learner centred teaching approach. The learner-centred methods recommended in the curriculum include teaching strategies such as case studies, brainstorming, field visits, panel discussion, story-telling, songs, group discussion, debate, posters, role play, games, projects, poetry recitals and drama (Ministry of Education, 2006).

Thirdly, subjects have been integrated into 'new learning areas'. In Learning Areas, related subject elements, are integrated to form a learning area. For example elements of Music, Dance, Physical-Education, Drama and Art are integrated to form Expressive Arts. Similarly English and Chichewa are integrated to form Literacy and Language with a focus in English or Chichewa (Ministry of Education, 2006). The learning areas are defined as an organised integrated body of knowledge, skills and values which serve as a basis for learning (Ministry of Education, 2006). Fourthly, the new curriculum has adopted continuous assessment. Continuous assessment is defined as a more individualised form of assessment in which learners have to be assessed in what they are able to do and display in each learning activity rather than assessing them at the end of the term or the year (Ministry of Education, 2006).

Lastly, the curriculum has a new structure of standard one, term one. In the curriculum, learning of content and literacy is delayed until term two. Term one is treated as a preparatory term in which the learners are oriented to school life through involvement in activities that will help them familiarise with the school environment and routine. In addition, the learners are engaged in activities that help in the development of sensory-motor skills such as games and plays. For this reason, term one is referred to as Introduction to school life and learning. The rationale behind the concept is that "in Malawi, most children come to primary school without any previous exposure to pre-school education (MIE, 2006, p.vi). The status of pre-school opportunities is best described by a 2006 report by the Ministry of Education. The report showed that:

There were 1,631 ECD centres in Malawi. The concentration of these centres is mainly in the urban areas, and the fees levied reduce the enrolments rates. The majority of children in the rural areas do not have access to these facilities. As a result, very few children below the age of five years have the opportunity to attend pre-school before joining formal primary education (Ministry of Education, 2006, p. 6).

As a result of such observations, the situation in terms of number of ECD centres has changed but the percentage of learners accessing pre-school still remains low and concentrated in urban and semi-urban areas. According to MOE (2006, p. 13), "there are 6,277 Early Childhood Development (ECD) centres as pre-schools. Only 30 percent of targeted pre-school children attend ECD centres. The majority of these centres are concentrated in urban and semi-urban areas."

The key features of the Outcomes Based Curriculum in Malawi and how it differs from its predecessors is summarised in table 2 below. 
Table 2. Features of the new curriculum in Malawi and how it differs from its predecessors

\begin{tabular}{|c|c|}
\hline 1991 Curriculum (Second Education Plan:1985-1995) & New curriculum (PCAR 2001) \\
\hline $\begin{array}{l}\text { Content based curriculum } \\
\text { The focus is on the achievement of objectives and coverage of } \\
\text { content mainly from the perspective of the teacher }\end{array}$ & $\begin{array}{l}\text { Outcomes based education - } \\
\text { The focus is on the outcomes displayed by the learner after } \\
\text { teaching and learning has taken place and Continuous } \\
\text { assessment is used as one main mode of assessment. }\end{array}$ \\
\hline $\begin{array}{l}\text { Number of subjects up to } 14 \\
\text { The subjects are: } \\
\text { Chichewa } \\
\text { English } \\
\text { Creative Arts } \\
\text { Social Studies } \\
\text { Mathematics } \\
\text { Music } \\
\text { Drama } \\
\text { Physical Education } \\
\text { Religious Studies } \\
\text { Needlecraft } \\
\text { Agriculture } \\
\text { Home Economics } \\
\text { Science/Health Education } \\
\text { Life skills }\end{array}$ & $\begin{array}{l}\text { Number of Learning areas up to } 9 \\
\text { The learning areas are: } \\
\text { Chichewa } \\
\text { English } \\
\text { Mathematics } \\
\text { Expressive Arts } \\
\text { Religious Education/Bible Knowledge } \\
\text { Life Skills } \\
\text { Social and Environmental Sciences } \\
\text { Agriculture } \\
\text { Science and Technology }\end{array}$ \\
\hline $\begin{array}{l}\text { Literacy skills development } \\
-\quad \text { The course aimed at literacy skills development }\end{array}$ & $\begin{array}{l}\text { Literacy and Numeracy skills development } \\
\text { The new focus is on acquisition of literacy and numeracy skills at } \\
\text { the earliest stage of the learners' schooling }\end{array}$ \\
\hline $\begin{array}{l}\text { Core versus Elective subjects } \\
\text { Some subjects were labelled core while others are not. This is } \\
\text { compounded by the examinations focus by Malawi National } \\
\text { Examination's Board (MANEB) who only examined the core subjects } \\
\text { at Primary School Leaving Certificate Examinations. The subjects } \\
\text { examined are: Mathematics, English, Chichewa, Science and Health, } \\
\text { Social Studies } \\
\text { The impact of this is arrangement was that only the core subjects } \\
\text { were emphasized and taught while the rest of the subjects were more } \\
\text { or less ignored. As a result many children were denied the privilege } \\
\text { of exposure to other subjects which are equally important to their } \\
\text { lives. }\end{array}$ & $\begin{array}{l}\text { All Learning Areas (Subjects) are Core } \\
\text { All the Learning Areas (Subjects) in the curriculum are core. } \\
\text { Malawi National Examinations Board (MANEB) examines all the } \\
\text { Learning Areas at Primary School Leaving Certificate } \\
\text { Examinations (PSLCE). The impact of this arrangement is that } \\
\text { all subjects in the curriculum are emphasized by the teachers. }\end{array}$ \\
\hline $\begin{array}{l}\text { Mostly has stand-alone subjects except for General Studies and } \\
\text { Social Studies } \\
\text { Most of the subjects stand alone and as a result the curriculum had } \\
\text { many subjects most of whom were apparently not being taught } \\
\text { although they appeared on the school time tables }\end{array}$ & $\begin{array}{l}\text { Integration of Subject Components } \\
\text { The integration has come about as a way of reducing the } \\
\text { overload but without losing subject matter. }\end{array}$ \\
\hline $\begin{array}{l}\text { Focused on Knowledge Acquisition } \\
\text { The curriculum attempted to impart knowledge using mainly teacher- } \\
\text { centred methodology }\end{array}$ & $\begin{array}{l}\text { Focuses on the acquisition of Skills, Concepts and } \\
\text { Knowledge as well as desirable attitudes and values } \\
\text { All learning areas/subjects aim at preparing learners for the } \\
\text { world of work through entrepreneurship skills. Various skills, } \\
\text { concepts, attitudes and values are earmarked for each learning } \\
\text { area. These become targets for achievement as outcomes to be } \\
\text { displayed by each learner. }\end{array}$ \\
\hline & $\begin{array}{l}\text { Incorporates emerging or cross-cutting issues } \\
\text { Democracy, Human Rights, Environment and Population have } \\
\text { mainly been featured in Social and Environmental Sciences } \\
\text { learning area as well in the literacy and languages of English } \\
\text { and Chichewa. } \\
\text { Issues of HIVIAIDS have mainly been incorporated in the Life } \\
\text { Skills, Social and Environmental Sciences, Agriculture, Science } \\
\text { and Technology, literacy and languages as well as in Expressive } \\
\text { Arts Learning area. }\end{array}$ \\
\hline
\end{tabular}

Source: Adapted from Kaambankadzanja (2011) 


\section{Discussion}

Although political, social and economic factors have shaped curriculum change and development in Malawi in recent times, the phenomenon of globalisation has been another influential factor in shaping curriculum change and development in Malawi when the country became a democratic government in 1994.

In a bid to pursue the global agenda, Malawi adopted an Outcomes-Based Education, based on South Africa's C2005. The adoption of an Outcomes-Based Education in Malawi could be attributed to the dominant role that South Africa plays in the SACD region. The SADC Protocol on education and training adopted in 1997 promoted an integrated qualifications framework, a key feature of the SA education and curriculum landscape. By 2004 a number of SADC countries including Malawi formulated a curriculum with a strong vocational and training. Consistent with Chisholm's (2005) argument that policies can circulate between levels, moving down from the international to the national and back to the regional, being reshaped in each stage and process to suit local circumstances, the South African C2005 has been reshaped when it was borrowed by Malawi in order to suit the local conditions in Malawi. For example, in comparison to South African C2005, the PCAR curriculum has included more content. However, in comparison to the 1991 curriculum produced under the Second Educational Plan in Malawi, the content in PCAR is more superficial because of integration of subjects approach taken by the curriculum.

In its bid to pursue the global agenda, Malawi borrowed the idea of OBE and integrated learning areas from South Africa's first major post-apartheid curriculum, Curriculum 2005. This borrowing happened despite the major review of C2005 that was taking place in South Africa in 2000 (DoE, 2000a), that had identified a range of weaknesses in C2005. The major weaknesses include the over design of the curriculum; and the underspecification of disciplinary forms of knowledge including 'no conceptual sequence and hence no learning progression path' (p. 150). The review committee strongly recommended reduced intergration and clearer specification of contents. The review of C2005 led to the Revised National Curriculum Statement (RNCS) in 2002. Due to ongoing criticism in the media of the 'persistent poor performance of learners on national and international tests' (Hoadley, 2011, p.152) a review of the RNCS was called for in 2009 by the new Minister of Education. The RNCS was revised once again in 2009 to formulate the Curriculum and Assessment Policy Statement (CAPS) that is currently being implemented in schools. The new CAPS (2009) has not only rejected OBE but has also emphasized knowledge to a greater extent (Hoadley, 2011).

Chisholm (2005) argued that the hegemonic influence of South Africa in the region may be exposing nation states in the region to the danger of 'unproblematic burrowing' which could be hazardous due to significant contextual differences with South Africa.

Whether Malawi will increasingly emphasize the prioritization of knowledge in the curriculum as SA curriculum reform from 1998 to 2009 has done remains to be seen.

\section{Conclusion}

Several factors have shaped curriculum change and development in Malawi. These factors border on political, social, economic and external influences, the most salient of these external influences being globalisation. As curriculum innovation is a continuous process, it is expected that curriculum planners in Malawi will be constantly changing the curriculum to respond to the needs of the country.

\section{References}

Adeyemi, M.B.\& Adeyinka (A.A. 2002). Some key issues in African Traditional Education. McGill Journal of Education.Vol.37, No.2, Spring, 2002. Gaborone. University of Botswana.

Apple, M.W. (1979). Ideology and Curriculum. London: Routledge.qualifications frameworks. Progress in Development, 7,1:65-78.

Chilimanjira, M.T. 2011. The extent to which the primary school curriculum and assessment reform (PCAR) language and literacy curriculum facilitates the acquisition of literacy skills in Standard Four Learners. The case of Four Schools in Blantyre Rural District. Unpublished Masters of Education Thesis. Zomba: Chancellor College.

Chilora, H.G.(2000). Language policy, research and practice in Malawi. Paper presented at the Comparative and International Education Society (CIES) 2000 Conference. San Francisco, USA.

Chisholm, L. (2005). The politics of curriculum review and revision in South Africa in regional context. In, Naidoo, D. 2009. Educational Theory and Enquiry 2. Course Reading Pack. Johannesburg: University of the Witwatersrand.

Dale, R and Robertson. (2002). Globalisation, Education and Development. Bristol: UK

DFID (Department for International Development). 2009. DFID Statistics on International Development. http://www. Gov.uk/government/organisations. accessed on the $7^{\text {th }}$ of July, 2009. 
Galimoto, P. (2008). Teaching Practice as component of teacher education in Malawi: An activity theory perspective. Unpublished PhD thesis, School of Education, University of Nottingham: Nottingham.

Hoadley, U. (2002). Curriculum: From Plans to Practice. Oxford: Oxford

Hoadley.2011. Knowledge, knowers and knowing. Curriculum reform in South Africa(pp.139-154). In L.Yates and M.Grummet(eds.).Curriculum in Today's World. Configuring knowledge identities, work and politics. Routledge.

Indire, F.(1983). 'Education in Kenya.' In A.B. Faunwa and J.U. Aisiku (eds). Education in Africa: A Comparative Survey. George Allen: London.

Jones, W. (2005). Curriculum for Entrepreneurship skills and practical subjects. TEVET: Lilongwe.

Kaambankadzanja, D.O.P. (2001). The changing role of primary school head teacher in Malawi. Unpublished Masters, University of Manchester, Manchester.

Kaambankadzanja, D. (2011). PCAR Process and the adaptation of outcomes based Education (OBE) Curriculum for the reform programme - A justification. Unpublished paper presented during the training for IPTE Curriculum Development. Domasi: Malawi Institute of Education.

Kabwila, V. (1995). Factors affecting the implementation of English, Social Studies, Music, Chichewa and Mathematics curricula implementation in Malawi. Unpublished Master of Education Research Report. Brandon University Brandon.

Khomani, P. (2003). Curriculum Development Process and the Malawi Experience. Domasi: Malawi Institute of Education.

Lowe, I. (2008). Policy and Practice in the teaching of Mathematics Education in the rural primary schools in Malawi. Unpublished PhD Thesis, Monash University, Melbourne. Available from arrow.monash.edu.au/hdl/1959.1/73686

MIE Library News. (2008). Malawi Institute of Education: Domasi.

Ministry of Education Science and Technology. (2006). Malawi Primary Education Curriculum and Assessment Framework. (Draft) Lilongwe: Ministry of Education.

Mohapeloa, J.(1982). 'Education in Lesotho.' In Fafunwa (ed), Education in Africa: a Comparative Survey. George Allen \& Unwin: London.

National AIDS Commission. (2004).Behavioural Surveillance Survey Report. Lilongwe: National AIDS Commission.

Oluniyi, O.2013. Curriculum Development in Nigeria: Historical Perspectives.Journal of Educational and Social Research, Vol.3(1) January 2013.

Spady, WG.(1994). Outcomes-Based Education. Critical Issues and Answers. American Association of School Administrators: Virginia.

South African Department of Education. (2000a). A South African Curriculum for the Twenty First Century: report of the Review Committee on Curriculum 2005, presented to the Minister of Education, Professor Kader Asmal, Pretoria: South African Department of Education.

Steiner-Khamisi, G.(2000). Policy Borrowing and Lending. London:Routeledge.

Tanner \& Tanner, L. (1980). Curriculum development (rev. ed.). Yonkerson, New York: World Book Co. 